\title{
CHILLING RESISTANCE OF SOMATIC HYBRIDS OF TOMATO AND POTATO
}

\author{
by \\ ROBERT M. SMILLIE \\ Plant Physiology Unit, Division of Food Research. \\ CSIRO and School of Biological Sciences, \\ Macquarie University, P. O. Box 52. North Ryde, Sydney, N.S.W. 2113 \\ GEORG MELCHERS \\ Max-Planck-Institut für Biologie. \\ Corrensstrasse 45, D-7400 Tübingen \\ and \\ DITER von WETTSTEIN \\ Department of Physiology, Carlsberg Laboratory, \\ Gamle Carlsberg Vej 10, DK-2500 Copenhagen, Valby
}

Keywords: Genes for chilling resistance, cytochrome $f$ reduction, photosynthetic electron transport

Chilling resistance was investigated in four somatic hybrid plants of tomato and potato. Tomato (Lycopersicon esculentum) is very susceptible to injury at chilling temperatures, whereas the other hybrid parent, potato (Solanum tuberosum), is relatively chilling resistant. Leaves of the four somatic hybrid plants and leaves of tomato and potato plants were detached and stored at $0^{\circ} \mathrm{C}$. Chilling resistance was determined by the rate of change in photosynthetic electron transfer activity in the stored leaves, as indicated by measurements of chloroplast cytochrome $f$ reduction. The chilling resistance of all four tomato-potato hybrids was intermediate between the chilling resistances of tomato and potato. Somatic hybrids produced by fusion of tomato and potato protoplasts may be useful for transferring genes for chilling resistance into the domestic tomato.

\section{INTRODUCTION}

Botanical data indicate that the cultivated tomato (Lycopersicon esculentum Mill.) and cultivated potato (Solanum tuberosum L.) both originated in the northern Andean region of
South America, but differed considerably in their altitudinal distribution. The ancestor of the cultivated tomato was originally confined to the narrow coastal strip of Ecuador and Peru (4, 7, 12) and from there spread throughout much of 
tropical America, including Mexico where it was first domesticated (4). In common with other plants derived from lowland regions in tropical latitudes, the tomato is susceptible to chilling injury, that is, both the plant and its fruit suffer damage with prolonged exposure to temperatures below $+10^{\circ} \mathrm{C}$. Wild potatoes are indigenous in the sierras of Peru and Bolivia at altitudes ranging from 2000 to nearly 5000 meters $(2,3,7)$. Night temperatures regularly fall below $10^{\circ} \mathrm{C}$ at altitudes above 2000 meters near the Equator $(10)$ and in contrast to tomatoes, potatoes are chilling resistant and show a much greater capacity to withstand temperatures below $+10^{\circ} \mathrm{C}$, but above freezing.

Recently Melchers, SaCristán and Holder (9) have identified a number of somatic hybrid plants of tomato and potato regenerated from fused tomato and potato protoplasts. Although Solanum is the genus most closely related to Lycopersicon (12), previous successful attempts to produce sexual hybrids of Lycopersicon esculentum and Solanum tuberosum are not known (9) and tomato-potato hybrids may be obtainable only by somatic hybridisation. The fact that the parent plants show a wide divergence in the degree of their chilling resistance provides an opportunity to follow the transfer of genetic information for chilling resistance through its expression in the hybrids.

The capacity for photosynthetic electron transfer declines rapidly in chilled leaves of chillingsensitive plants $(6,8)$ and this appears to be one of the earliest detectable manifestations of chilling injury in leaves (5). Smilue and NotT (14) compared susceptibility to chilling injury in leaves of various tomato species by measuring the photoreductive activity of chloroplasts isolated from chilled leaves. While the limited amount of leaf material available precluded use of this method for assaying susceptibility to chilling injury in the tomato-potato hybrids, the state of the photosynthetic electron transfer system in chilled hybrid leaves may be ascertained by measurements of the photooxidation and dark reduction of chloroplast cytochrome $f$, in a way analogous to that used to compare heat sensitivity in leaves of different plant species (13). Using this in vivo assay, chilling resistance was compared in leaves of tomato and potato and the four previously identified tomato-potato hybrids.

\section{METHODS}

Procedures for producing the four somatic hybrids of S. tuberosum, dihaploid stock $\mathrm{HH} 258$ and $L$. esculentum var. cerasiforme, mutant yellow green 6, RICK, used in this study are detailed by Melchers et al. (9). Each of the hybrids is from a different group of plants that originated from different regimes of callus transfers. The hybrids are designated $1 b / 2 h / 3$, $6 a / 4 z / 6 g, 6 b / 1 x / 2 a$ and $7 a / 20 e$ (referred to hereafter as $l b, 6 a, 6 b$ and $7 a$, respectively), these codes indicating the protocols of the callus transfer and shoot regenerations of the four groups of plants regenerated from fusions of potato and tomato protoplasts (9). The four hybrids grafted onto tomato stock var. Supravite, and plants of S. tuberosum stock $\mathrm{HH} 258$ and L. esculentum var. Supravite (hybrid of $» \mathrm{De}$ Enkhuizer Zaadhandel«, Enkhuizen, Holland) were grown in a glass-house at Copenhagen with a day temperature of about $25^{\circ} \mathrm{C}$ and a night temperature of $20^{\circ} \mathrm{C}$.

To measure susceptibility to chilling injury, leaves were detached and placed in Petri dishes containing moistened filter paper. The dishes were embedded in melting ice in a light-proof container stored in a cold room $\left(2^{\circ}\right.$ to $\left.5^{\circ} \mathrm{C}\right)$. Unchilled samples of leaves were similarly stored in Petri dishes at about $18^{\circ} \mathrm{C}$ in darkness. Changes in photosynthetic electron transfer activity in individual leaves were assayed by rapidly warming the leaves to $23^{\circ} \mathrm{C}$ and recording the rate of dark reduction of cytochrome $f$ (cytochrome-554) following a 30second period of illumination. The absorbance increase at $554 \mathrm{~nm}$ coinciding with cytochrome reduction was monitored using an Aminco DW-2a spectrophotometer operated in the dual wavelength mode (reference wavelength 541 $\mathrm{nm}$ ). The upper surface of each leaf was positioned at $45^{\circ} \mathrm{C}$ to the measuring and actinic beams. The actinic light beam from a 150-watt tungsten-halogen lamp was filtered through Schott BG 18 and RG 695 filters. A Corning blue-green filter (4-96) was placed between the leaf and the photomultiplier. Three cycles each of 30 -seconds of illumination followed by 90 - 
seconds of darkness were employed for each measurement and the values obtained for cycles 2 and 3 were averaged. The rate of cytochrome reduction immediately following the period of illumination is given as the time in seconds taken for the absorbance to increase $50 \%$ of the difference between the light and dark steady-state absorbance values.

\section{Table I}

Susceptibility of tomato-potato hybrid leaves to chilling injury as measured by in vivo changes in reduction of cytochrome $f$ following illumination.

The reduction of cytochrome $f$ immediately following a 30-second period of illumination was measured as described in Materials and Methods. Values for cytochrome reduction are the $t / 1 / 2$ for the reduction in seconds ( \pm standard error of the mean) obtained using leaves detached and stored at $0^{\circ} \mathrm{C}$ or $18^{\circ} \mathrm{C}$ for the periods indicated in the table. The first value for each plant is for freshly detached leaves.

\begin{tabular}{|c|c|c|c|c|}
\hline \multirow[b]{2}{*}{ Plant } & \multicolumn{2}{|c|}{ Storage Conditions } & \multirow{2}{*}{$\begin{array}{l}\text { No. of } \\
\text { measure- } \\
\text { ments }\end{array}$} & \multirow{2}{*}{$\begin{array}{l}\text { Rate of dark } \\
\text { cytochrome } \\
\text { reduction }\end{array}$} \\
\hline & $\begin{array}{c}\text { Temperature } \\
\left({ }^{\circ} \mathrm{C}\right)\end{array}$ & $\begin{array}{c}\text { Duration } \\
(\mathrm{hr})\end{array}$ & & \\
\hline \multirow[t]{6}{*}{ Tomato } & - & 0 & 6 & $13.0 \pm 1.5$ \\
\hline & 0 & 22 & 10 & $2.0 \pm 0.1$ \\
\hline & 0 & 47 & 7 & $1.1 \pm 0.1$ \\
\hline & 0 & 92 & 5 & $0.76 \pm 0.07$ \\
\hline & 0 & 166 & 4 & $0.55 \pm 0.05$ \\
\hline & 18 & 72 & 10 & $12.2 \pm 0.5$ \\
\hline \multirow[t]{6}{*}{ Potato } & - & 0 & 6 & $16.3 \pm 1.3$ \\
\hline & 0 & 46 & 8 & $14.5 \pm 0.6$ \\
\hline & 0 & 92 & 8 & $12.2 \pm 0.8$ \\
\hline & 0 & 122 & 11 & $7.1 \pm 0.4$ \\
\hline & 0 & 166 & 6 & $3.9 \pm 0.3$ \\
\hline & 18 & 72 & 4 & $16.0 \pm 0.8$ \\
\hline \multirow{5}{*}{$\begin{array}{l}\text { Tomato-potato } \\
\text { hybrid, } 6 \mathrm{a}\end{array}$} & - & 0 & 4 & $19.2 \pm 1.1$ \\
\hline & 0 & 46 & 6 & $12.3 \pm 0.7$ \\
\hline & 0 & 92 & 9 & $6.9 \pm 0.3$ \\
\hline & 0 & 168 & 3 & $0.93 \pm 0.07$ \\
\hline & 18 & 92 & 3 & $19.0 \pm 0.6$ \\
\hline \multirow{5}{*}{$\begin{array}{l}\text { Tomato-potato } \\
\text { hybrid, 7a }\end{array}$} & - & 0 & 3 & $14.3 \pm 0.3$ \\
\hline & 0 & 19 & 3 & $10.0 \pm 1.1$ \\
\hline & 0 & 46 & 6 & $7.5 \pm 0.3$ \\
\hline & 0 & 92 & 6 & $5.7 \pm 0.5$ \\
\hline & 0 & 168 & 2 & $1.9 \pm 0.1$ \\
\hline \multirow{4}{*}{$\begin{array}{l}\text { Tomato-potato } \\
\text { hybrid, Ib }\end{array}$} & - & 0 & 4 & $19.7 \pm 2.3$ \\
\hline & 0 & 46 & 6 & $7.8 \pm 0.7$ \\
\hline & 0 & 92 & 7 & $5.0 \pm 0.4$ \\
\hline & 0 & 168 & 3 & $1.6 \pm 0.2$ \\
\hline \multirow{4}{*}{$\begin{array}{l}\text { Tomato-potato } \\
\text { hybrid, } 6 \mathrm{~b}\end{array}$} & - & 0 & 4 & $21.7 \pm 0.8$ \\
\hline & 0 & 46 & 6 & $11.8 \pm 1.1$ \\
\hline & 0 & 92 & 8 & $5.3 \pm 0.7$ \\
\hline & 0 & 168 & 5 & $0.88 \pm 0.05$ \\
\hline
\end{tabular}




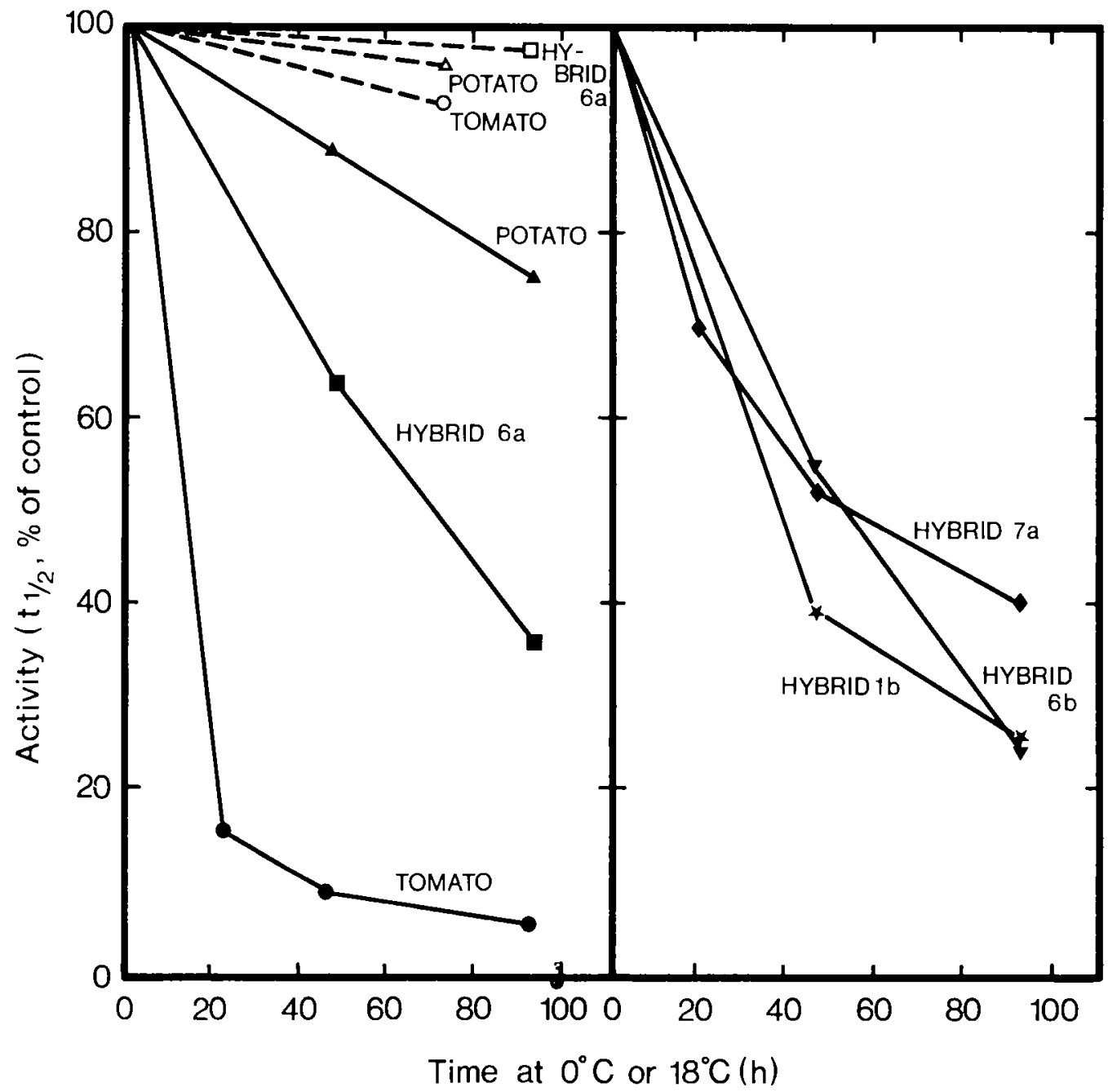

Figure 1. Changes in rate of cytochrome $f$ reduction in leaves of tomato, potato and tomato-potato hybrids during chilling at $0^{\circ} \mathrm{C}$. Conditions are as described in Table $\mathrm{I}$. Values for the rate of dark cytochrome reduction given in Table I for leaves stored at $0^{\circ} \mathrm{C}$ and $18^{\circ} \mathrm{C}$ are expressed as a percentage of the value for the freshly detached leaves (control rate). Open symbols indicate leaves stored at $18^{\circ} \mathrm{C}$; closed symbols indicate storage at $0^{\circ} \mathrm{C}$.

\section{RESULTS AND DISCUSSION}

The relative susceptibilities of the tomatopotato hybrid leaves to chilling injury as measured by changes in the sdark" reduction of cytochrome $f$ in chilled leaves are given in Table I. The same measurements were made using leaves of S. tuberosum stock $\mathrm{HH} 258$ and $\mathrm{L}$. esculentum var. Supravite grown under the same conditions. To allow direct comparisons of the chilling-induced changes in the different plants, the rates given in Table $I$ for each plant are plotted in Figure 1 as a percentage of the rate obtained with the freshly detached leaves.

It was previously shown (10) that photosynthetic reductive activity in chloroplasts isolated from chilled leaves was lost within 24 to 48 hours in several varieties of L. esculentum and a tropical form of the wild tomato $\mathrm{L}$. hirsutum. This loss of activity took at least 2 days longer in a high altitude form of L. hirsutum which has an enhances tolerance towards chilling injury (10). Chloroplasts isolated from $\mathrm{L}$. esculentum and $\mathrm{L}$. 
hirsutum leaves stored at $10^{\circ} \mathrm{C}$ did not show changes in photosynthetic electron transfer activity. In intact leaves, these changes in photosynthetic electron transfer activity induced by severe chilling at $0^{\circ} \mathrm{C}$ can be followed by monitoring light-induced changed in cytochrome $f$ oxidation and reduction (14), absorbance changes at $518 \mathrm{~nm}$, or chlorophyll fluorescence (R. M. Smillie, unpublished experiments).

The rate of dark reduction of cytochrome $f$ in tomato leaves decreased markedly during the first 22 hours at $0^{\circ} \mathrm{C}$ (Figure 1). There was little change in this activity in leaves stored at $18^{\circ} \mathrm{C}$ for 72 hours. The tomato variety used in these experiments is not the one used to produce the hybrids, as the mutant yellow green tomato parent is light-sensitive and was not available at the time of the experiments as comparable plants growing in the glass-house. The time course for changes in photosynthetic electron transfer activity at $0^{\circ} \mathrm{C}$ in the hybrid variety Supravite is similar to other varieties of $\mathrm{L}$. esculentum previously examined (14).

As might be expected of a chilling tolerant plant, changes in the rate of dark reduction of cytochrome $f$ in potato leaves kept at $0^{\circ} \mathrm{C}$ developed much more slowly than in the chilling-sensitive tomato. After 92 hours at this temperature the rate had changed by only $25 \%$ (Figure 1). It is interesting that chilling-induced changes were detectable in potato, these becoming quite pronounced after 4 days at $0^{\circ} \mathrm{C}$ (Table I). Thus the potato is not entirely resistant to a chilling stress when the temperature is as low as $0^{\circ} \mathrm{C}$. This is consistent with other observations. The sweetening of potatoes stored at low temperatures $\left(<8^{\circ} \mathrm{C}\right)$ is well known and BURTON (1) points out that storing potatoes just above their freezing point at $-1^{\circ} \mathrm{C}$ increases the period of dormancy and may permanently impair the ability to grow.

The four tomato-potato hybrids showed similar degrees of chilling resistance and all were intermediate in resistance between potato and tomato (Figure 1). After 168 hours at $0^{\circ} \mathrm{C}$ the rate of dark reduction of cytochrome $f$ in the hybrids was about the same as found in tomato after 47 hours at $0^{\circ} \mathrm{C}$ (Table I). A chilling resistance in the interspecific hybrids intermediate between that of parent species might be expected if both tomato and potato nuclear genes affecting chilling resistance are expressed in the hybrids. Melchers, SACRISTÁN and Holder (9) have shown by analyzing the subunit polypeptide pattern of ribulose-1,5-bisphosphate carboxylase prepared from the four hybrids that in every case the small subunit of the enzyme resulted from the expression of both tomato and potato nuclear genes. Analysis of the large subunit polypeptides of the same enzyme, which are coded for by chloroplast DNA, revealed hybrids $6 \mathrm{a}, 6 \mathrm{~b}$ and lb to carry functional chloroplast DNA from tomato while in the fourth hybrid, $7 \mathrm{a}$, the functional chloroplast DNA was derived from potato. The chilling resistance of this latter hybrid is close to the range of the other three hybrids. Expression of potato chloroplast DNA thus did not provide a chilling resistance comparable to that exhibited by potato leaves, notwithstanding the fact that cytochrome $f$ happens to be coded for by chloroplast DNA (J. C. GraY, personal communications). The intermediate chilling resistance in all four plants is in agreement with the previous conclusion that the plants are somatic hybrids with expression of nuclear genes from both tomato and potato. The chromosome number and the expression of the genes for the small subunit of ribulose-bisphosphate carboxylase indicate hybrid $7 \mathrm{a}$ to be a hexaploid arisen by fusion of two potato and one tomato protoplast and thus containing 4 potato and 2 tomato genomes (9). This hybrid is therefore expected to be more chilling resistant than the others. The hybrid was somewhat more chilling tolerant than the other hybrids after 92 and 168 hours of storage. Further studies are required to substantiate this difference.

In recent times, tomatoes have grown in popularity to become one of the most important vegetables grown for human consumption; for instance, the yield of tomatoes in the United States in 1977 was higher than for any other vegetable produced commercially (11). Aside for allowing an extended growing season, the introduction of genes for chilling resistance into commercial tomatoes may make it possible to use low temperature to increase the postharvest storage life of the fruit. The somatic tomatopotato hybrids which have flowered have not produced seeds. The infertility is perhaps due to aneuploidy and triploidy respectively, as evidenced by the chromosomal counts (9, and MeL- 
CHERS and SACRISTÁN, unpublished). Several of the somatic hybrids can, however, be successfully propagated by cuttings and by grafting of scions. Transfer of the genes for chilling resistance from potato to tomato with the aid of a somatic hybrid requires genetic exchange between the potato and tomato chromosomes either by induced homoeologous pairing followed by crossing-over or by induced reciprocal translocations. A further prerequisite is the haploidisation of the two genomes after effected genetic exchange. This would be easiest if a somatic tomato-potato hybrid could be identified which gives viable gametes, either to be used in self- and cross-fertilisation or in the regeneration of dihaploid plants. In order to identify the rare chilling-resistant recombinants in the tomato genome, simple and rapid screening techniques on small leaf samples are necessary. The techniques employed in the present study point the way towards the development of such procedures. It has recently been proposed to select for chilling resistance among the progeny of sexual hybrids of $\mathrm{L}$. esculentum and high altitude forms of the wild tomato $\mathrm{L}$. hirsutum (10). The extension of this approach to tomatopotato hybrids offers one advantage, namely that a potato parent can be chosen which is considerably more chilling resistant than high altitude forms of L. hirsutum (15).

\section{REFERENCES}

I. Burton, W. G.: The physics and physiology of storage. In: The Potato Crop. P. M. Harris, ed. Chapman \& Hall, London, pp. 545-606 (1978)

2. Correll. D. S.: The Potato and its Wild Relatives. Texas Research Foundation: Renner (1962)

3. HAWKes, J. G.: History of the potato. In: The Potato Crop. P. M. HaRRIs, ed., Chapman \& Hall, London, pp. 1-14 (1978)..
4. Jenkins, J. A.: The origin of the cultivated tomato. Econ. Bot. 21, 379-392 (1948)

5. KislyuK, I. M.: Morphological and functional changes of chloroplasts after cooling of leaves of Cucumis sativus L. In: The Cell and Environmental Temperature. A. S. Troshin, ed., Pergamon Press, Oxford, pp. 59-63 (1967)

6. KisLyuk, I. M. \& M. D. VAs'KovSKII: Effect of cooling cucumber leaves on photosynthesis and photochemical reactions. Sov. Plant Physiol. 19, 813-18 (1972)

7. Luckwill, L. C.: The genus Lycopersicon. Aberdeen Univ. Studies No. 120. The University Press, Aberdeen (1943)

8. Margules, M. M. \& A. T. JAGendorf: Effect of cold storage of bean leaves on photosynthetic reactions of isolated chloroplasts. Arch. Biochem. Biophys. 90, 176-183 (1960)

9. Melchers, G, M. D. Sacristán \& A. A. HOLDER: Somatic hybrid plants of potato and tomato regenerated from fused protoplasts. Carlsberg Res. Commun. 43, 203-218 (1978)

10. Patterson, B. D., R. Paull \& R. M. Smillie: Chilling resistance in Lycopersicon hirsutum Humb. \& Bonpl., a wild tomato with a wide altitudinal distribution. Aust. J. Plant Physiol. 5, 609-617 (1978)

11. Rrck, C. M.: The tomato. Sci. Amer. 239, 7787 (1978)

12. Rick, C. M. \& L. Butler: Cytogenetics of the tomato. Adv. in Genetics 3, 267-382 (1956)

13. Smillie, R. M.: Coloured components of chloroplast membranes as intrinsic membrane probes for monitoring the development of heat injury in intact tissue. Aust. J. Plant Physiol. 6, (1979)

14. Smillie, R. M. \& R. Notr: Assay of chilling injury in wild and domestic tomatoes based on photosystem activity of chilled leaves. Plant Physiol., in press (1979)

15. Smiluie, R. M.: The useful chloroplast: A new approach for investigating chilling stress in plants. In: Low temperature stress in Crop plants: The role of the membrane. J. M. Lyons, J. K. Raison \& D. Graham, eds., Academic Press, New York, in press (1979) 